\title{
Organosolv Modified Wheat Straw as Adsorbent for Basic Dyes in Water Bodies
}

\author{
Dimitrios Sidiras, Ioanna Salapa, Dorothea Politi \\ Laboratory of Simulation of Industrial Processes \\ Department of Industrial Management \& Technology, School of Maritime \& Industry, University of Piraeus \\ 80 Karaoli \& Dimitriou, GR 18534 Piraeus, Greece \\ sidiras@unipi.gr; isalapa@unipi.gr,doritapoliti@yahoo.gr
}

\begin{abstract}
Biomass and especially lignocellulosic residues offer a low-cost and renewable additional source of adsorbents and can be used as is or modified or transformed to activated carbon. These waste materials have little or no economic value and often present a disposal problem. Therefore, there is a drive to valorize these low-cost by-products. Various low-cost adsorbents from agricultural byproducts have been studied to remove dyes from aqueous solutions. In this work, a sulfuric acid-catalyzed organosolv pretreatment process using five organic solvents, i.e., ethanol, methanol, diethylene glycol, acetone and butanol, was applied to modify wheat straw under carefully selected conditions. The low-cost material, i.e., modified wheat straw was used as adsorbent for cleaning of water bodies' pollution. The potentiality of modified wheat straw for the adsorptive removal of Methylene Blue (MB), a representative basic dye, from aqueous solutions was studied. The experimental batch adsorption system data were simulated using (a) Freundlich, Langmuir and Sips isotherm models and (b) first order, second order and intraparticle diffusion kinetic models.
\end{abstract}

Keywords: adsorption, methylene blue, organosolv, pretreatment, sulfuric acid, wheat straw

\section{Introduction}

The contamination of water due to color effluents coming from different industries is a current problem all over the world [1]. Textile dyes and other industrial dyestuffs form one of the largest groups of organic compounds that represent an increasing environmental danger by releasing toxic and potential carcinogenic substances into the aqueous phase. Textile industry requires about 700,000 t of different types of dyes for the annually world production [2]. Textile industries wastewater is known to contain considerable amounts of non-fixed dyes, azo dyes, and a quantity of inorganic salts. The most of the dyes used in dyeing processes are released into the environment, which causes considerable environmental pollution problems [1]. Therefore, many methods are available for the removal of dyes from industrial effluents. The most widely used are biodegradation [3], flocculation-coagulation [4], chemical oxidation [5] and adsorption. Among these methods, the adsorption technique has been proven to be effective and attractive for the treatment of dye-bearing wastewaters [6].

During the past decades, activated carbon (AC) is the most commonly used adsorbent. However, the AC suffers from some drawbacks such as high cost, difficult disposal and regeneration [7]. Recently, increasing attention was paid on the development of highly effective and low cost adsorbents [8-10]. In this respect, renewable adsorbents are attractive because of their low cost, easy availability and low toxicity. Various renewable materials, such as peanut husk [11], wheat straw [12], cotton stalk [13], sugar beet pulp [14], pistachio hull [15], papaya seeds [16], and fruit peel [17], have been used as adsorbent for the removal of dye from aqueous solution.

In this work, the removal of MB by wheat straw modified by sulfuric acid catalyzed organosolv pretreatment was studied using untreated wheat straw as control. The adsorption isotherms and adsorption kinetics of MB were used to estimate and compare the adsorption capacity of the untreated and pretreated wheat straw.

\section{Materials \& Methods}

Wheat straw sulfuric acid-catalyzed organosolv pretreatment process with (i) ethanol, (ii) methanol, (iii) diethyleneglycol, (iv) acetone and (v) butanol as organic solvent was used to produce absorbents for methylene blue cleaning. The organosolv pretreatment process was performed in a 3.75-L batch reactor PARR 4843. The isothermal treatment times was 
20 and 40 min (not including the non-isothermal preheating and the cooling time-periods); the reaction was catalyzed by sulfuric acid and organic acids produced by the wheat straw during the reaction conditions; the liquid-to-solid ratio was 20:1; the liquid phase volume was $2000 \mathrm{~mL}$, i.e., $1000 \mathrm{~mL}$ organic solvent and $1000 \mathrm{~mL}$ water; the solid material dose was $100 \mathrm{~g}$; the stirring speed $150 \mathrm{rpm}$. The reaction ending temperature values were $160^{\circ} \mathrm{C}$ and $180^{\circ} \mathrm{C}$, reached after 42 and 62 min preheating time values, respectively.

The dye used in batch experiments was Methylene Blue produced by Allfa Aesar GmbH and Co KG, Karlsruhe, Germany. $\mathrm{MB}$ has a chemical formula of $\mathrm{C}_{16} \mathrm{H}_{18} \mathrm{ClN}_{3} \mathrm{~S}_{2} \mathrm{xH}_{2} \mathrm{O}$ with molecular weight of $319.8610^{-3} \mathrm{~kg} \mathrm{~mol}{ }^{-1}$. A stock solution was prepared by dissolving $5 \mathrm{~g}$ of $\mathrm{MB}$ in $25 \mathrm{~L}$ distilled water. Working solutions were 1.6-156 mg L $\mathrm{L}^{-1} \mathrm{MB}^{-15}$ concentrations were analyzed by measuring the absorbent values in each experiment with a HACH LANGE DR6000 spectrophotometer at $\lambda=664 \mathrm{~nm}$.

Isotherms were obtained from batch experiments. After the batch process, weigh accurately the quantities of tissue were transferred to $0.8-\mathrm{L}$ bottles, where $\mathrm{V}=0.5 \mathrm{~L}$ adsorbate solution were added. The adsorbent weight was $0.5 \mathrm{~g}$, the temperature was $\mathrm{T}=23^{\circ} \mathrm{C}$, the original $\mathrm{MB}$ concentration ranged from $\mathrm{C}_{0}=1.6 \mathrm{mg} \mathrm{L}^{-1}$ to $156 \mathrm{mg} \mathrm{L}^{-1}$. The bottles were sealed and mechanically filled for a period of 7 days. This time period was chosen after pilot studies (the time varies from 4 hours to 14 days) to ensure that nearly equilibrium conditions are achieved. The resulting solution was determined concentrations and balance data from each bottle represented one point on the adsorption isotherm plots. The values of solution $\mathrm{pH}$ were near 8 .

As regards the accuracy of the results the Mean Average Percentage Error was $0.39 \%$ for kinetic experiments and $1.2 \%$ for isotherm experiments.

Adsorption rate batch experiments were conducted in a 2-L glass totally mixed reactor equipped with a twisted blade agitator type, operating at $600 \mathrm{rpm}$, for maintaining the lignocellulosic material in suspension. The reactor, containing $\mathrm{V}=$ $1 \mathrm{~L}$ aqueous solution of dye was placed in a water bath to maintain constant temperature at the desired level. The adsorbent mass was $\mathrm{m}=1 \mathrm{~g}$, the temperature was $23^{\circ} \mathrm{C}$, the initial concentration of $\mathrm{MB}$ was $\mathrm{C}_{0}=14 \mathrm{mg} \mathrm{L}^{-1}$.

\section{Results \& Discussion}

The comparison of the adsorption capacity of the seaweed samples was based on the Freundlich [18], Langmuir [19] and Sips [20] isotherm models. The first two models are both widely used for investigating the adsorption of a plethora of dyes on various lignocellulosic materials and activated carbons. The Freundlich [18] isotherm is given by the following equation:

$$
q=K_{F} \cdot\left(C_{e}\right)^{\frac{1}{n}}
$$

where $q$ is the amount adsorbed per unit mass of the adsorbent $\left(\mathrm{mg} \mathrm{g}^{-1}\right), \mathrm{C}_{\mathrm{e}}$ is the equilibrium concentration of the adsorbate $\left(\mathrm{mg} \mathrm{L}^{-1}\right)$ and $K_{F}\left[\left(\mathrm{mg} \mathrm{g}^{-1}\right)\left(\mathrm{L} \mathrm{mg}^{-1}\right)^{1 / \mathrm{n}}\right], n$ are the Freundlich constants related to adsorption capacity and intensity, respectively. The $K_{F}$ and $\mathrm{n}$ values were estimated by non-linear regression analysis (NLRA) from the experimental adsorption data obtained at $23{ }^{\circ} \mathrm{C}$ for $\mathrm{MB}$. The standard error of estimates (SEE)-values was calculated by the following equation:

$$
S E E=\sqrt{\sum_{i=1}^{n^{\prime}}\left(y_{i}-y_{i, \text { theor }}\right)^{2} /\left(n^{\prime}-p^{\prime}\right)}
$$

where: $y_{i}$ is the experimental value of the depended variable, $y_{i, \text { theor }}$ is the theoretical (estimated) value of the depended variable, $n^{\prime}$ is the number of the experimental measurements and $\mathrm{p}^{\prime}$ is the number of parameters, i.e., $\left(n^{\prime}-p^{\prime}\right)$ is the number of the degrees of freedom. The parameters of the Freundlich adsorption model can be obtained by NLRA.

The Langmuir isotherm equation [19] is based on the following 'pseudo-monolayer' adsorption model.

$$
q=\frac{K_{L} q_{m} C_{e}}{1+K_{L} C_{e}} \quad \text { or } \quad \frac{1}{q}=\left(\frac{1}{q_{m}}\right)+\left(\frac{1}{K_{L} \cdot q_{m}}\right) \cdot\left(\frac{1}{C_{e}}\right)
$$



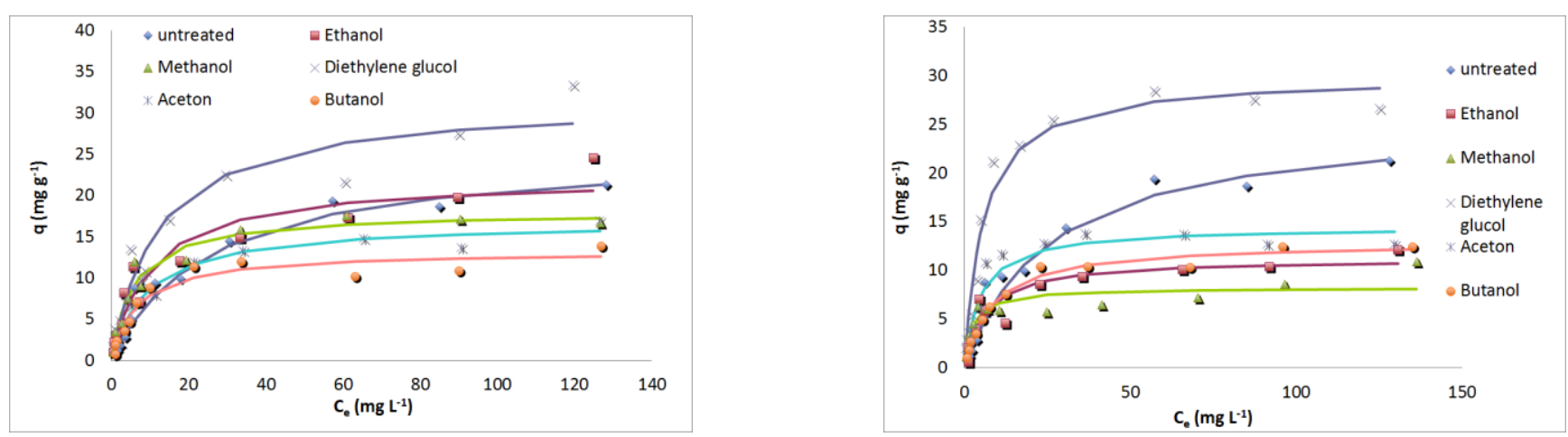

Fig. 1: Langmuir isotherms for MB adsorption on modified wheat straw at $160{ }^{\circ} \mathrm{C}$ for $20 \mathrm{~min}$ (left) and $40 \mathrm{~min}$ (right).

Table 1: Parameters of Freundlich and Langmuir isotherm models of Methylene Blue adsorption on modified wheat straw.

\begin{tabular}{|c|c|c|c|c|c|c|}
\hline & \multicolumn{3}{|c|}{ Freundlich isotherm model } & \multicolumn{3}{|c|}{ Langmuir isotherm model } \\
\hline Pretreatment & $K_{F}$ & $n$ & $S E E$ & $q_{m}$ & $K_{L}$ & $S E E$ \\
\hline Untreated & 2,79 & 2,28 & 2,12 & 25,65 & 0,0392 & 1,51 \\
\hline \multicolumn{7}{|l|}{$160^{\circ} \mathrm{C}, 20 \mathrm{~min}$} \\
\hline Ethanol & 3,98 & 2,71 & 1,80 & 22,26 & 0,0987 & 2,32 \\
\hline Methanol & 4,82 & 3,46 & 2,29 & 18,07 & 0,1731 & 1,27 \\
\hline $\begin{array}{l}\text { Diethylene } \\
\text { glycol }\end{array}$ & 5,14 & 2,60 & 2,58 & 31,67 & 0,0836 & 2,71 \\
\hline Acetone & 3,38 & 2,92 & 2,01 & 16,94 & 0,1045 & 1,15 \\
\hline Butanol & 3,28 & 3,31 & 2,01 & 13,27 & 0,1483 & 1,17 \\
\hline \multicolumn{7}{|l|}{$160^{\circ} \mathrm{C}, 40 \mathrm{~min}$} \\
\hline Ethanol & 2,86 & 3,31 & 1,42 & 11,27 & 0,1585 & 1,37 \\
\hline Methanol & 3,14 & 4,37 & 1,17 & 8,24 & 0,4068 & 1,25 \\
\hline $\begin{array}{l}\text { Diethylene } \\
\text { glycol }\end{array}$ & 8,02 & 3,47 & 4,63 & 30,06 & 0,1785 & 1,86 \\
\hline Acetone & 4,52 & 3,94 & 2,72 & 14,53 & 0,2106 & 1,41 \\
\hline Butanol & 2,95 & 3,19 & 1,34 & 12,93 & 0,1207 & 0,55 \\
\hline \multicolumn{7}{|l|}{$180^{\circ} \mathrm{C}, 20 \mathrm{~min}$} \\
\hline Ethanol & 3,43 & 3,74 & 1,95 & 11,78 & 0,1824 & 1,19 \\
\hline Methanol & 2,12 & 3,85 & 1,23 & 6,86 & 0,2016 & 1,09 \\
\hline $\begin{array}{l}\text { Diethylene } \\
\text { glycol }\end{array}$ & 4,26 & 2,92 & 2,31 & 20,67 & 0,1196 & 2,39 \\
\hline Acetone & 2,74 & 2,27 & 1,85 & 23,49 & 0,0527 & 2,32 \\
\hline Butanol & 1,45 & 1,97 & 1,66 & 20,20 & 0,0273 & 2,01 \\
\hline
\end{tabular}

where $\mathrm{K}_{\mathrm{L}}$ is the Langmuir constant related to the energy of adsorption $\left(\mathrm{L} \mathrm{mg}^{-1}\right)$ and $\mathrm{q}_{\mathrm{m}}$ the amount of dye adsorbed $\left(\mathrm{mg} \mathrm{g}^{-1}\right)$ when saturation is attained. In cases where the isotherm experimental data approximates the Langmuir equation, the parameters $\mathrm{K}_{\mathrm{L}}$ and $\mathrm{q}_{\mathrm{m}}$ can be estimated either by plotting $1 / \mathrm{q}$ versus $1 / \mathrm{C}_{\mathrm{e}}$ either by NLRA.

The Sips (Langmuir - Freundlich) [20] isotherm equation, also examined in the present work, is based on the following adsorption model:

$$
q=\frac{q_{m} \cdot\left(K_{L} \cdot C_{e}\right)^{1 / n}}{1+\left(K_{L} \cdot C_{e}\right)^{1 / n}}
$$



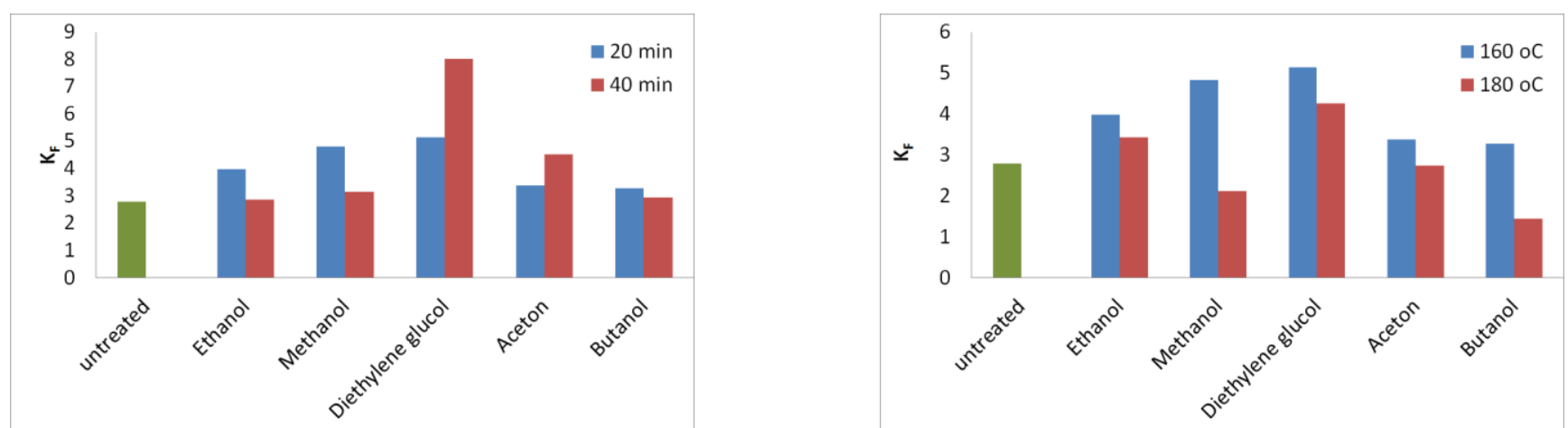

Fig. 2: Isotherm parameter $K_{F}$ according to the Freundlich model of MB adsorption on modified wheat straw at $160{ }^{\circ} \mathrm{C}$ for 20 min and 40 (left) and at 160 and $180{ }^{\circ} \mathrm{C}$ for 20 min (right).
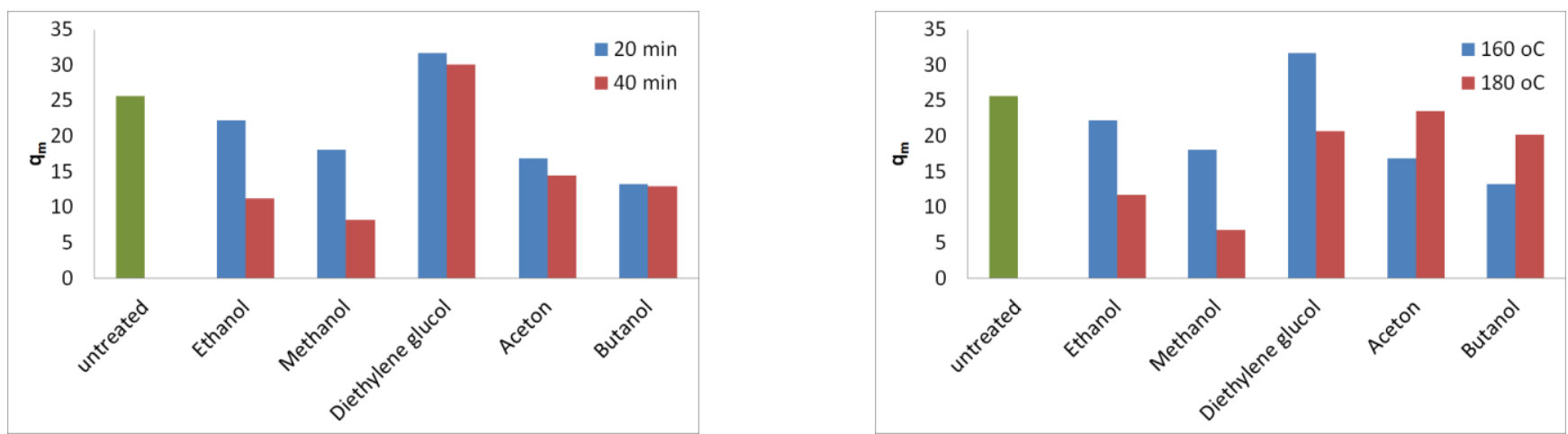

Fig. 3: Isotherm parameter $q_{m}$ according to the Langmuir model of MB adsorption on modified wheat straw at $160{ }^{\circ} \mathrm{C}$ for 20 min and 40 (left) and at 160 and $180{ }^{\circ} \mathrm{C}$ for $20 \mathrm{~min}$ (right).

where $K_{L}, q_{m}$ is the Langmuir constants and $n$ the Freundlich constant.

The fitting of the Langmuir's adsorption model to the MB adsorption experimental data was satisfactory as can be seen in Fig.1. In Table 1 the estimated parameter values and the SEE for Freundlich and Langmuir isotherms are presented. The low SEE values prove the good fitting of these models on the experimental data. In Fig. 3 the Freundlich isothermparameter $\mathrm{K}_{\mathrm{F}}$ values estimated using NLRA are presented. Similarly, in Fig. 4 the Langmuir isotherm-parameters $q_{m}$ estimated using NLRA are presented.

Kinetic models' equations: The kinetics of adsorption of MB on various materials has been extensively studied using three kinetic equations. The widely used Lagergren equation [21] is shown below:

$$
q-q_{t}=q \cdot e^{-k \cdot t}
$$

where $\mathrm{q}$ and $\mathrm{q}_{\mathrm{t}}$ are the amounts of $\mathrm{MB}$ adsorbed per unit mass of the adsorbent (in $\mathrm{mg} \mathrm{g}^{-1}$ ) at equilibrium time $(t \rightarrow \infty)$ and adsorption time $\mathrm{t}$, respectively, while $\mathrm{k}$ is the pseudo-first order rate constant for the adsorption process (in $\left.\min ^{-1}\right)$. Furthermore, $q=\left(C_{0}-C_{e}\right) V / m$ and $q_{t}=\left(C_{0}-C\right) V / m$ where $\mathrm{C}, \mathrm{C}_{0}, \mathrm{C}_{\mathrm{e}}$ are the concentrations of MB in the bulk solution at time $\mathrm{t}, 0$, and , respectively, while $\mathrm{m}$ is the weight of the adsorbent used (in $\mathrm{g}$ ), and $\mathrm{V}$ is the solution volume (in $\mathrm{mL}$ ). The commonly used second-order kinetic model [22] is as follows: 

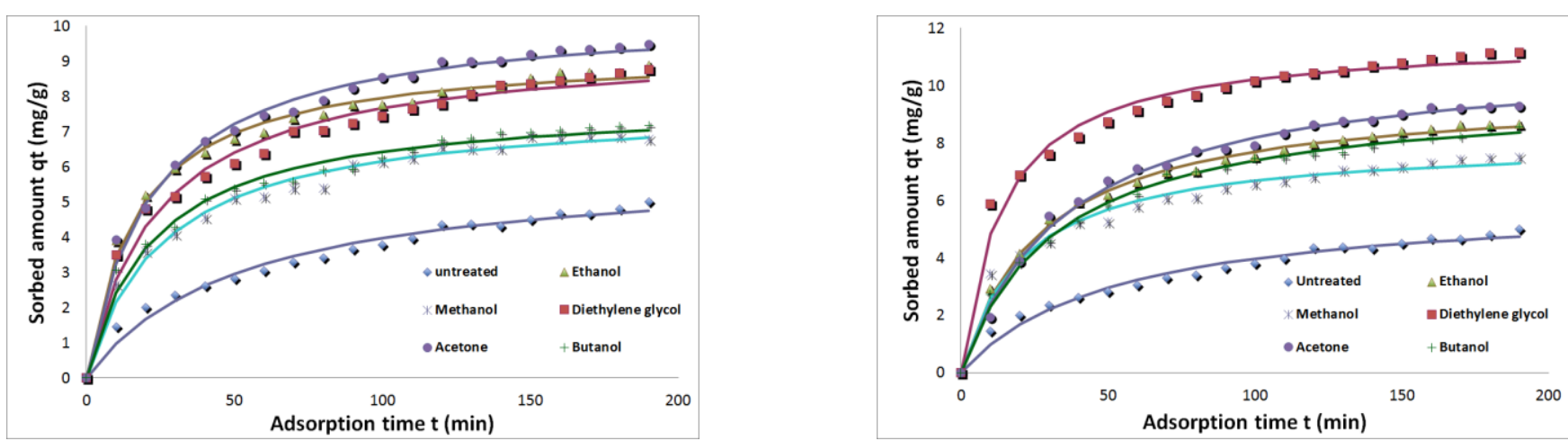

Fig. 4: Kinetics according to the second order model of MB adsorption on modified wheat straw at $160{ }^{\circ} \mathrm{C}$ for $20 \mathrm{~min}$ (left) and $40 \mathrm{~min}$ (right).

Table 2: Parameters of $1^{\text {st }}$ and $2^{\text {nd }}$ order kinetic models for Methylene Blue adsorption on modified wheat straw.

\begin{tabular}{|c|c|c|c|c|c|c|}
\hline & \multicolumn{3}{|c|}{$1^{\text {st }}$ order kinetic model } & \multicolumn{3}{|c|}{$2^{\text {nd }}$ order kinetic model } \\
\hline Pretreatment & $k\left(\min ^{-1}\right)$ & $q\left(m g g^{-1}\right)$ & $S E E$ & $k\left(g \mathrm{mg}^{-1} \mathrm{~min}^{-1}\right)$ & $q\left(m g g^{-1}\right)$ & $S E E$ \\
\hline Untreated & 0.0184 & 4.80 & 0.270 & 0.0032 & 6.045 & 0.199 \\
\hline \multicolumn{7}{|l|}{$160^{\circ} \mathrm{C}, 20 \mathrm{~min}$} \\
\hline Ethanol & 0.0420 & 8.23 & 0.471 & 0.0063 & 9.310 & 0.215 \\
\hline Methanol & 0.0303 & 6.63 & 0.365 & 0.0050 & 7.750 & 0.214 \\
\hline $\begin{array}{l}\text { Diethylene } \\
\text { glycol }\end{array}$ & 0.0316 & 8.19 & 0.523 & 0.0044 & 9.510 & 0.302 \\
\hline Acetone & 0.0343 & 9.02 & 0.462 & 0.0044 & 10.412 & 0.225 \\
\hline Butanol & 0.0334 & 6.81 & 0.418 & 0.0056 & 7.873 & 0.241 \\
\hline \multicolumn{7}{|l|}{$160^{\circ} \mathrm{C}, 40 \mathrm{~min}$} \\
\hline Ethanol & 0.0301 & 8.30 & 0.358 & 0.0038 & 9.789 & 0.147 \\
\hline Methanol & 0.0346 & 7.06 & 0.469 & 0.0059 & 8.092 & 0.276 \\
\hline $\begin{array}{l}\text { Diethylene } \\
\text { glycol }\end{array}$ & 0.0474 & 10.46 & 0.672 & 0.0061 & 11.650 & 0.338 \\
\hline Acetone & 0.0254 & 9.11 & 0.272 & 0.0025 & 11.127 & 0.192 \\
\hline Butanol & 0.0265 & 8.16 & 0.314 & 0.0031 & 9.803 & 0.159 \\
\hline \multicolumn{7}{|l|}{$180^{\circ} \mathrm{C}, 20 \mathrm{~min}$} \\
\hline Ethanol & 0.0073 & 11.76 & 0.211 & 0.0003 & 18.571 & 0.226 \\
\hline Methanol & 0.0242 & 7.65 & 0.368 & 0.0030 & 9.240 & 0.234 \\
\hline $\begin{array}{l}\text { Diethylene } \\
\text { glycol }\end{array}$ & 0.0524 & 9.36 & 0.607 & 0.0078 & 10.352 & 0.298 \\
\hline Acetone & 0.0110 & 11.62 & 0.193 & 0.0005 & 16.980 & 0.242 \\
\hline Butanol & 0.0137 & 8.69 & 0.096 & 0.0009 & 12.080 & 0.164 \\
\hline
\end{tabular}

$$
q_{t}=q-\left[q^{-1}+k_{2} t\right]^{-1} \quad \text { or } \quad q_{t}=q-\frac{1}{\frac{1}{q}+k_{2} t}
$$

where $\mathrm{k}_{2}\left(\mathrm{~min}^{-1}\right)$ is the rate constant of second order adsorption. The kinetic model parameters can be obtained by NLRA. The fitting of this adsorption model to the experimental data was very satisfactory as is shown in Fig.4; this can be proved by the corresponding SEE-values presented in Table 2. The parameters $k_{2}$ and $q$ of this model are presented in the same Table 2. The MB maximum amount adsorbed vs. the different adsorption materials, as represented by the parameter $q$ value, estimated for the pretreated wheat straw was significantly higher than the value corresponding to the untreated 
Table 3: Parameters of intraparticle kinetic model for Methylene Blue adsorption on pretreatment wheat straw.

\begin{tabular}{|c|c|c|c|}
\hline Pretreatment & $c\left(m g g^{-1}\right)$ & $k_{p}\left(m g g^{-1} \min ^{-0.5}\right)$ & SEE \\
\hline Untreated & 0.35 & 0.3437 & 0.132 \\
\hline \multicolumn{4}{|l|}{$160^{\circ} \mathrm{C}, 20 \mathrm{~min}$} \\
\hline Ethanol & 2.28 & 0.5291 & 0.743 \\
\hline Methanol & 1.32 & 0.4525 & 0.477 \\
\hline Diethylene glycol & 1.71 & 0.5554 & 0.558 \\
\hline Acetone & 2.07 & 0.6027 & 0.721 \\
\hline Butanol & 1.53 & 0.4571 & 0.512 \\
\hline \multicolumn{4}{|l|}{$160^{\circ} \mathrm{C}, 40 \mathrm{~min}$} \\
\hline Ethanol & 1.54 & 0.5755 & 0.598 \\
\hline Methanol & 1.68 & 0.4675 & 0.533 \\
\hline Diethylene glycol & 3.28 & 0.6473 & 1.018 \\
\hline Acetone & 1.10 & 0.6645 & 0.682 \\
\hline Butanol & 1.24 & 0.5772 & 0.525 \\
\hline \multicolumn{4}{|l|}{$180^{\circ} \mathrm{C}, 20 \mathrm{~min}$} \\
\hline Ethanol & -1.23 & 0.7259 & 0.448 \\
\hline Methanol & 1.05 & 0.5403 & 0.411 \\
\hline Diethylene glycol & 3.13 & 0.5670 & 0.967 \\
\hline Acetone & -0.82 & 0.8265 & 0.458 \\
\hline Butanol & -0.39 & 0.6520 & 0.397 \\
\hline
\end{tabular}
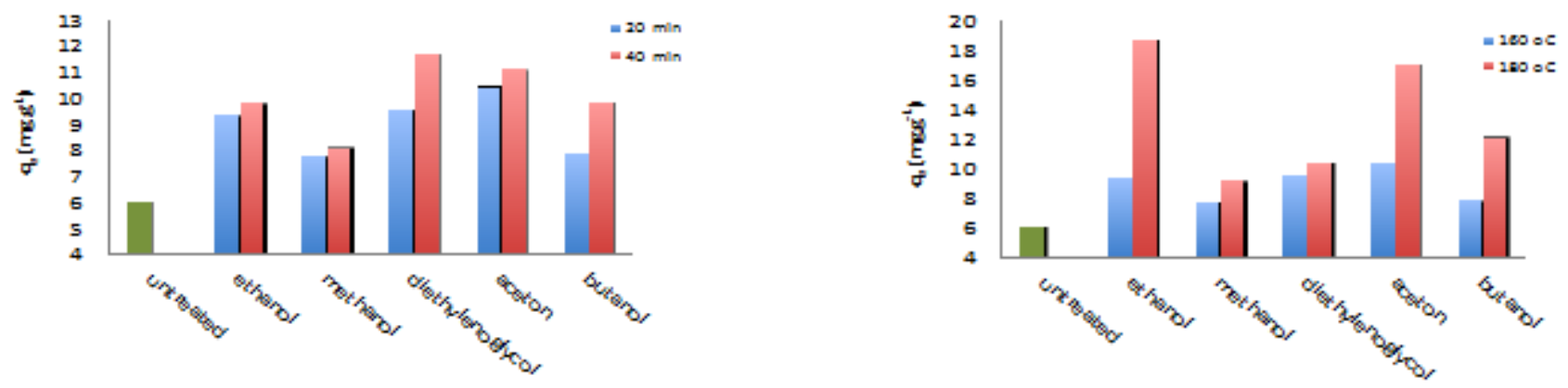

Fig. 5: Kinetic parameter $q$ according to the second order model of MB adsorption on modified wheat straw at $160{ }^{\circ} \mathrm{C}$ for 20 min and 40 (left) and at 160 and $180{ }^{\circ} \mathrm{C}$ for $40 \mathrm{~min}$ (right).

sample (see Table 2 and Fig. 5). The possibility of intra-particle diffusion was explored by using the intra-particle diffusion model [23]:

$$
q_{t}=c+k_{p} \cdot \sqrt{t}
$$

where $q_{t}$ is the amount of MB adsorbed at time $\mathrm{t}, \mathrm{c}$ is a constant $\left(\mathrm{mg} \mathrm{g}^{-1}\right)$ and $\mathrm{k}_{\mathrm{p}}$ is the intra-particle diffusion rate constant in $\mathrm{mg} \mathrm{g}^{-1} \mathrm{~min}^{-0.5}$. In Table 3 the parameters of intra-particle diffusion model are presented. Tables 3 presents the estimated the intra-particle diffusion kinetic model parameter values and the corresponding SEE values for the experimental data obtained in the present study. In Fig. 6, the intra-particle diffusion kinetic model parameter $k_{p}$ values estimated for MB adsorption on untreated and pretreated wheat straw and are given. The $k_{p}$ values for pretreated straw are significantly higher that the value for untreated material. The highest $k_{p}$ value was obtained in the case of acetone treated straw. 

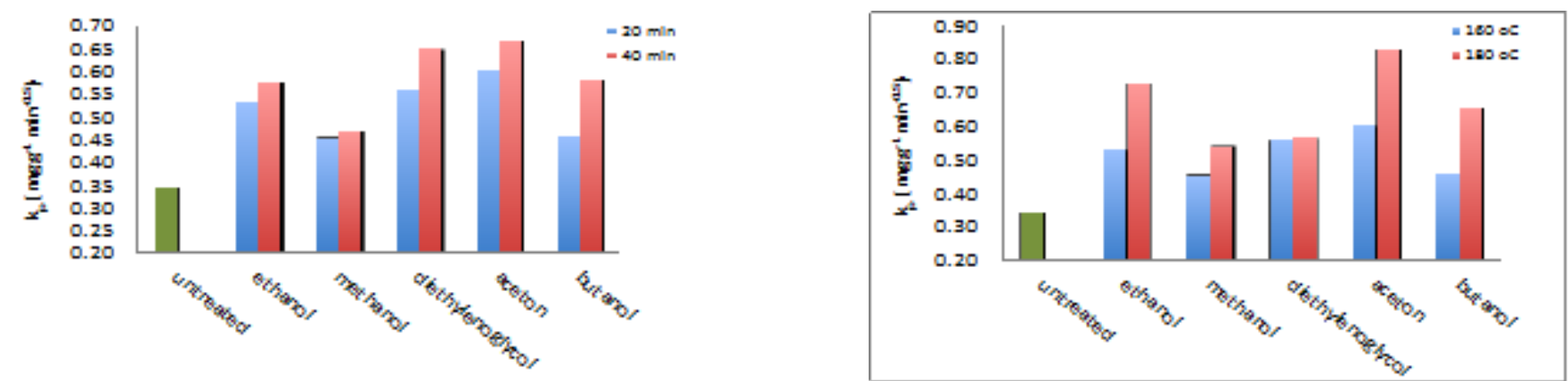

Fig. 6: Kinetic parameter $k_{p}$ according to the intraparticle diffusion model of MB adsorption on modified wheat straw at $160{ }^{\circ} \mathrm{C}$ for 20 min and 40 (left) and at 160 and $180{ }^{\circ} \mathrm{C}$ for 40 min (right).

\section{Conclusion}

According to the above results, organosolv treatment of the wheat straw enhances considerably the materials adsorption properties as regards basic dyes cleaning, like $\mathrm{MB}$, from aquatic environment. Thus, this low-cost widely available material could be used as an alternative adsorbent to commercial activated carbons. The adsorption kinetic data were found to follow the pseudo-second-order kinetic model. Nevertheless, the intra-particle diffusion model was also applicable giving a maximum adsorption rate constant $k_{p}$ equal to 0.827 as regards wheat straw pretreated with acetone at $180{ }^{\circ} \mathrm{C}$ for $20 \mathrm{~min}$; this modified material is appropriate for fast adsorption processes. On the other hand, the isotherm results recommend the use of diethylene glycol pretreated wheat straw, at $160{ }^{\circ} \mathrm{C}$ for $20 \mathrm{~min}$, for high adsorption capacity $q_{m}=31.7 \mathrm{mg} / \mathrm{g}$. The decision as regards the use of a specific solvent for the wheat straw pretreatment must be based on the priorities of each adsorption technological application.

\section{Acknowledgements}

Financial support by the Research Centre of the University of Piraeus is kindly acknowledged.

\section{References}

[1] X. Xiao, F. Zhang, Z. Feng, S. Deng and Y. Wang, "Adsorptive removal and kinetics of methylene blue from aqueous solution using NiO/MCM-41 composite," Physica E., vol. 65, pp. 4-12, 2015.

[2] A. M. Talarposhti, T. Donelly and G. K. Anderson, "Colour removal from a simulated dye wastewater using a twophase anaerobic packed bed reactor," Water Res., vol. 35, no.2, pp. 425-432, 2001.

[3] M. M. El-Sheekh, M. M. Gharieb and G. W. Abou-El-Souod, "Biodegradation of dyes by some green algae and cyanobacteria," Int. Biodeterior. Biodegrad., vol. 63, pp. 699-704, 2009.

[4] 6 P. Canizares, F. Martinez, C. Jimenez, J. Lobato and M.A. Rodrigo, "Coagulation and electrocoagulation of wastes polluted with dyes," Environ. Sci. Technol., vol. 40, pp. 6418-6424, 2006.

[5] I.A. Salem and M.S. El-Maazawi, "Kinetics and mechanism of color removal of methylene blue with hydrogen peroxide catalyzed by some supported alumina surfaces," Chemosphere, vol. 41, pp. 1173-1180, 2000.

[6] Y. Yao, F. Xu, M. Chen, Z. Xu and Z. Zhu, "Adsorption is a comparatively cheap process and effective in the removal of dyes," Bioresour. Technol., vol.101, pp. 3040-3046, 2010.

[7] S. Dutta, A. Bhattacharyya, A. Ganguly, S. Gupta and S. Basu, "Application of response surface methodology for preparation of low-cost adsorbent from citrus fruit peel and for removal of methylene blue," Desalination, vol. 275, pp. 26-36, 2011.

[8] Z. Aksu, "Application of biosorption for the removal of organic pollutants: a review," Process Biochemistry, vol. 40, pp. 997-1026, 2005.

[9] V. K. Gupta and Suhas, "Application of low-cost adsorbent for dye removal: A review," Journal of Environmental Management, vol. 90, pp. 2313-2342, 2009.

[10] L. Zhou, J. Huang, B. He, F. Zhang, H. Li, "Peach gum for efficient removal of methylene blue and methyl violet dyes from aqueous solution," Carbohydrate Polymers, vol. 101, pp. 574-581, 2014.

[11] J. Song, W. Zou, Y. Bian, F. Su, R. Han, "Adsorption characteristics of methylene blue by peanut husk in batch and column modes," Desalination, vol. 265, pp. 119-125, 2011. 
[12] F. Batzias, D. Sidiras, E. Schroeder, C. Weber, "Simulation of dye adsorption on hydrolyzed wheat straw in batch and ifxe $\square$-bed systems," Chem. Eng. J., vol. 148, pp. 459-472, 2009.

[13] H. Deng, J. Lu, G. Li, G. Zhang, X. Wang, "Adsorption of methylene blue on adsorbent materials produced from cotton stalk,” Chem. Eng. J., vol. 172, pp. 326-334, 2011.

[14] M. Malekbala, S. Hosseini, S. K. Yazdi, S. Masoudi Soltani, "The study of the potential capability of sugar beet pulp on the removal efficiency of two cationic dyes," Chem. Eng. Res. Des., vol. 90, pp. 704-712, 2012.

[15] G. Moussavi and R. Khosravi, "The removal of cationic dyes from aqueous solutions by adsorption onto pistachio hull waste," Chem. Eng. Res. Des., vol. 89, pp. 2182-2189, 2011.

[16] B. H. Hameed, "Evaluation of papaya seeds as a novel non-conventional low-cost adsorbent for removal of methylene blue," J. Hazard. Mater., vol. 162, pp. 939-944, 2009.

[17] B. H. Hameed and H. Hakimi, "Utilization of durian (Durio zibethinus Murray) peel as low cost sorbent for the removal of acid dye from aqueous solutions," Biochem. Eng. J., vol. 39, pp. 338-343, 2008.

[18] H. M. F. Freundlich, "Über die adsorption in lösungen," Zeitschrift für Physikalische Chemie., vol. 57, pp. 385-471, 1906.

[19] I. Langmuir, "The constitution and fundamental properties of solids and liquids," Journal of American Chemical Society, vol. 38, pp. 2221-2295, 1916.

[20] R. Sips, "Structure of a catalyst surface," Journal of Chemical Physics, vol. 16, pp. 490-495, 1948.

[21] S. Lagergren, "Zur theorie der sogenannten adsorption gelöster stoffe," Kungliga Svenska Vetenskapsakademiens, Handlingar, vol. 24, pp. 1-39, 1898.

[22] Y. S. Ho, J. C. Y. Ng, and G. McKay, "Kinetics of pollutants sorption by biosorbents: review," Separation and Purification Methods, vol. 29, pp. 189-232, 2000.

[23] W. J. Weber and J. C. Morris, "Kinetics of adsorption on carbon from solution," Journal of the Sanitary Engineering Division, vol. 89, pp. 31-60, 1963. 